\title{
A DISTRIBUTED REAL-TIME MODEL OF DEGRADATION IN A SOLID OXIDE FUEL CELL, PART I: MODEL CHARACTERIZATION
}

V. Zaccaria ${ }^{1 *}$, D. Tucker ${ }^{1}$, A. Traverso ${ }^{2}$

${ }^{1}$ U.S. Department of Energy, NETL, Morgantown, WV, USA

${ }^{2}$ Thermochemical Power Group, Università di Genova, Genova, Italy

* Corresponding author: 3610 Collins Ferry Rd, Morgantown, WV 26507 valentina.zaccaria@netl.doe.gov

\begin{abstract}
Despite the high efficiency and flexibility of fuel cells, which make them an attractive technology for the future energy generation, their economic competitiveness is still penalized by their short lifetime, due to multiple degradation phenomena. As a matter of fact, electrochemical performance of solid oxide fuel cells (SOFCs) is reduced because of different degradation mechanisms, which depend on operating conditions, fuel and air contaminants, impurities in materials, and others. In this work, a real-time, one dimensional (1D) model of a SOFC is used to simulate the effects of voltage degradation in the cell. Different mechanisms are summarized in a simple empirical expression that relates degradation rate to cell operating parameters (current density, fuel utilization and temperature), on a localized basis. Profile distributions of different variables during cell degradation are analyzed. In particular, the effect of degradation on current density, temperature, and total resistance of the cell are investigated. An analysis of localized degradation effects shows how different parts of the cell degrade at a different time rate, and how the various profiles are redistributed along the cell as consequence of different degradation rates.
\end{abstract}

Keywords: $S O F C$, real-time model, cell degradation

\section{Nomenclature}

FU Fuel utilization

LSM Lanthanum - Strontium - Manganite

PEN Positive side - Electrolyte Negative side

SOFC Solid oxide fuel cell

TPB Triple phase boundary

WGS Water gas shift

YSZ Yttria-stabilized zirconia
$\mathrm{A}_{\text {channel }}$ Cross-sectional area of the channel for conduction heat transfer $\left[\mathrm{m}^{2}\right]$ $\mathrm{A}_{\text {gas }}$ Area of convective heat transfer between gas and solid $\left[\mathrm{m}^{2}\right]$

$A_{\text {react }}$ Area of reaction $\left[\mathrm{m}^{2}\right]$

$c_{p} \quad$ Specific heat $\left[\mathrm{J} \cdot \mathrm{kg}^{-1} \cdot \mathrm{K}^{-1}\right]$

F Faraday's constant $\left[\mathrm{C} \cdot \mathrm{mol}^{-1}\right]$

$\mathrm{G} \quad$ Gibbs free energy $[\mathrm{kJ}]$ 


$\begin{array}{ll}\mathrm{K}_{\mathrm{p}} & \text { equilibrium constant } \\ \mathrm{i} & \text { current density }\left[\mathrm{A} \cdot \mathrm{cm}^{-2}\right] \\ \mathrm{i}_{0} & \text { exchange current density }\left[\mathrm{A} \cdot \mathrm{cm}^{-2}\right] \\ \mathrm{n} & \text { number of electrons transfer per } \\ & \text { reaction } \\ \mathrm{p} & \text { partial pressure }[\mathrm{Pa}] \\ \mathrm{R} & \text { area specific resistance }\left[\Omega \cdot \mathrm{m}^{2}\right] \\ \mathrm{r}_{\mathrm{d}} & \text { degradation rate }\left[\% \cdot \mathrm{kh}^{-1}\right] \\ \mathrm{r}_{\mathrm{sr}} & \text { reformed methane } \mathrm{rate}\left[\mathrm{mol} \cdot \mathrm{s}^{-1}\right] \\ \mathrm{R}_{\mathrm{g}} & \text { ideal gas constant }\left[\mathrm{J} \cdot \mathrm{mol}^{-1} \cdot \mathrm{K}^{-1}\right] \\ \mathrm{T} & \text { temperature }[\mathrm{K}] \\ \mathrm{t} & \text { time }[\mathrm{h}] \\ \mathrm{th} & \text { thickness }[\mathrm{m}] \\ \mathrm{V} & \text { voltage }[\mathrm{V}] \\ \mathrm{x} & \text { mole fraction }\end{array}$

\section{Symbols}

$\begin{array}{ll}\alpha & \text { charge transfer coefficient } \\ \eta & \text { electrochemical loss }[\mathrm{V}] \\ \rho & \text { resistivity }[\Omega \cdot \mathrm{m}] \\ \rho_{\mathrm{s}} & \text { solid density }\left[\mathrm{kg} \cdot \mathrm{m}^{-3}\right]\end{array}$

\section{Subscripts}

$\begin{array}{ll}\text { act } & \text { activation } \\ \text { an } & \text { anode } \\ \text { ca } & \text { cathode } \\ \text { dif } & \text { diffusion } \\ \text { el } & \text { electrolyte } \\ \text { irr } & \text { irreversible } \\ \text { ohm } & \text { ohmic }\end{array}$

\section{Introduction}

Several mechanisms of degradation affect high temperature fuel cells, from electrode delamination and electrolyte cracking to electrode poisoning and microstructure coarsening [14]. Some mechanisms cause a decrement in power output at constant current and others can result in catastrophic failure of the cell. The nature of these mechanisms is different, and many models have been developed to analyze different types of degradation, causes and possible corrective actions [5-10]. In the work from Verda et al., a CFD model of a SOFC is developed in order to simulate the degradation of anode, cathode, and electrolyte due to instabilities or electrolyte delamination [5]. Virkar models different degradation phenomena to investigate the effect of a single cell failure in a stack [6]. The effect of trace species in the anode is studied by Ryan et al., where different degradation mechanisms are classified based on their physical effect on the cell [7]. Gazzarri and Kesler develop a finite elements model of a SOFC to analyze the impact of different degradation mechanisms on the impedance, proposing a method for degradation modes identification [8]. A correlation between open circuit voltage and sulfur concentration in the fuel is proposed by Nagel et al., who investigate the impact of reforming activity on cell performance [9]. A model of different degradation processes is used by Nakajo et al. to study the effect of operating conditions on SOFC lifetime [10]. In this work, a simplified model is developed for real-time applications that takes into account localized degradation in the 
fuel cell. This work is critical for cyber-physical hardware simulations of hybrid system performance and impact on fuel cell operability.

Although the variety of degradation phenomena, all the diverse mechanisms and degradation modes are affected by operating parameters such as current density, temperature and fuel utilization, which can be controlled [4, 11-16]. For example, it was observed that high operating temperature promoted lower cell degradation by reducing cathode overpotential [10]. In addition, temperature distribution governs the location of the highest current density zone, where a stronger degradation is induced [16]. Fuel utilization affects the distribution of fuel composition over the active area of the cell, resulting in different localized degradation distributions [10,17]. High fuel utilization can lead to oxidation of the anode material at the anode-electrolyte interface [18].

In a previous work, the effect of overall degradation of a SOFC was modeled for real-time applications $[19,20]$. An empirical function for the degradation rate (in terms of percentage of voltage drop per 1,000 hours of operation) was previously extrapolated from experimental data and incorporated in the SOFC model, first at a global level [19] and then on a localized basis, taking into account also the effect of the temperature [21]. A simple algebraic expression, a function of current density, temperature, and fuel utilization, was used to achieve real-time performance of the model, with the final goal of coupling the fuel cell model with the hardware components of a fuel cell gas turbine hybrid emulator. It has been posed that the common effect of all degradation mechanisms can be seen as an increment in the area specific resistance (ASR) of the cell $[17,18,22]$. For simplicity, the degradation rate was incorporated in the model as an incrementing factor in the ohmic resistance.

In this work, the effect of localized degradation in a SOFC is analyzed using a real-time distributed model. In Part I, the degradation model and the employed methodology are described. The behavior of the main parameters during cell degradation is analyzed. In the Part II, a more detailed analysis of several fuel cell parameters is presented, along with the effect of degradation on heat generation, temperature gradients, and overpotential [23]. In this second part, the possible causes of failure are pointed out, in order to determine a future control strategy that can mitigate degradation effects. 


\section{SOFC model}

A 1D, real-time model is used to simulate a co-flow, planar anode-supported SOFC, composed of a Ni doped yttria-stabilized zirconia (Ni-YSZ) anode, a YSZ- lanthanum strontium magnetite (LSM) cathode, and YSZ electrolyte [24]. The model employed in this work was previously developed with the goal of integrating it into a SOFC gas turbine hybrid system emulator [25]. Maintaining real-time capability while capturing the localized degradation effects is the main objective of this work.

The model employs a coupled approach of finite difference and finite volume, respectively for thermal and electrochemical equations. Since the electrochemistry models do not use differential equations, the finite volume approach is more appropriate. For heat transfer, the only way to meet the real-time requirement is to use a finite difference method. A mixed approach is necessary to meet both the accuracy and real-time requirements. The cell is discretized in 20 volumes (or nodes) in the direction of fuel and air flows. Properties such as temperature, pressure, and concentration are assumed to be uniform in each control volume. Variables such as current density, Nernst potential, temperatures and fuel composition are calculated on a distributed basis, in each node and for each sample time. The following equations are used in the model to calculate Nernst potential (Eq. 1), cell voltage (Eq. 2), and overpotentials (Eq. 3-5). The Butler-Volmer equation for the activation losses is approximated in Eq. 4 according to the approach presented by Noren and Hoffman [26]. Since each electrode contributes to the activation polarization, Eq. 4 is applied to both anode and cathode. The expressions for exchange current densities, $i_{0}$, are illustrated in Equations 6 and 7.

$$
\begin{aligned}
& V_{\text {NERNST }}=-\frac{\Delta G_{H_{2} O}^{\mathrm{D} O}}{n F}+\frac{R_{g} T}{n F} \ln \left(\frac{p_{H_{2}} \sqrt{p_{O_{2}}}}{p_{H_{2} O} \mathrm{O}}\right) \\
& V_{c e l l}=V_{\text {NERNST }}-\eta_{\text {dif }}-\eta_{\text {act }}-\eta_{\text {ohm }} \\
& \eta_{\text {dif }}=\frac{R_{g} T}{2 F}\left(\ln \left(\frac{x_{H_{2} b u l k} x_{H_{2}} O_{2} T P B}{x_{H_{2} O b_{i} \text { bulk }} x_{H_{2}} T P B}\right)+\frac{1}{2} \ln \left(\frac{x_{O_{2} \text { bulk }}}{x_{O_{2} T P B}}\right)\right) \\
& \eta_{a c t}=\frac{R_{g} T}{\alpha n F} \sinh ^{-1}\left(\frac{\tilde{i}}{2 i_{0}}\right) \\
& \eta_{o h m}=R \cdot i
\end{aligned}
$$


$i_{0, a n}=5.5 \cdot 10^{8} \frac{p_{H_{2}}}{p_{a m b}} \frac{p_{H_{2} O} \mathrm{O}}{p_{a m b}} \exp \left(-\frac{50 \cdot 10^{\mathrm{g}}}{R_{g} T}\right)$

$i_{0, c a}=7 \cdot 10^{8}\left(\frac{p O_{z}}{p_{a m b}}\right)^{0.25} \exp \left(-\frac{100-10^{\mathrm{g}}}{R_{g} T}\right)$

The total cell resistance is calculated according to Equation 8, in which degradation contributes to increase the ohmic resistance, shown in Equation 9 where the resistivity $\rho$ is function of the temperature and $R^{\prime \prime}{ }_{\text {oxide }}$ is a constant value equal to $1.6^{*} 10^{-6} \Omega \cdot \mathrm{m}^{2}$. Interconnects are assumed to have negligible impact on bulk material ohmic losses due to high electronic conductivity. Oxide scaling and other specific mechanisms of ohmic losses are lumped into the empirically derived parameters for degradation. Degradation contribution is expressed in terms of the coefficient $r_{d}$, presented in Equation 10, and with the term $R_{i r r}$, which represents the irreversible contribution of degradation and whose value is updated at each sample time according to Equation 11. Time in Eq. 8 is in hours, and accelerated simulations were carried out considering a second of simulation equivalent to an hour of degradation.

Although all the most common degradation phenomena affect all the overpotential terms, in this model, degradation rate impact is incorporated only on the ohmic resistance, and consequently ohmic losses.

$R=\left(R_{\text {ohm }}+R_{\text {irr }}\right) \cdot\left(1+r_{d} \cdot \frac{t}{1000}\right)$

$R_{\text {ohm }}=R_{\text {PEN }}+R_{\text {oxide }}^{\prime \prime}=\rho_{a n} t h_{a n}+\rho_{e l} t h_{e l}+\rho_{c a} t h_{c a}+R_{\text {oxide }}^{\prime \prime}$

$r_{d}=\frac{0.59 F U+0.74}{1+\exp \left(\frac{T-10.87}{22.92}\right)}\left(e^{2.64 i}-1\right)$

$R_{\text {irr }}=\sum_{\text {time }}\left(R_{\text {pEN }}+R_{\text {oxide }}^{n g}\right) \times \frac{r_{d}}{1000}$

The algebraic expression of Eq. 10 was found using a curve fitting approach from experimental data (degradation rate at different temperatures, current densities and fuel utilizations), as described in previous works, in which details about the choice of the coefficients can be found $[19,21]$. Degradation rate values were calculated from voltage measurements in different conditions, with a maximum standard deviation of $\pm 16 \%$. Degradation rate in terms of $\% \cdot(\mathrm{kh})^{-1}$ of voltage decay was assumed to follow an exponential trend with respect to current density and to increase with decreasing temperature [14]. In the initial work, the coefficient for current 
density driven degradation was dependent on temperature [19]. To incorporate temperature dependence in the rate expression shown in Equation 10, the coefficient for current density (2.64 $\mathrm{cm}^{2} \mathrm{~A}^{-1}$ ) was held constant and another temperature dependent term was added [21]. Additional impact of fuel impurities on degradation rate was neglected in this work, but will be part of future studies.

The expression of Eq. 10 was observed to match the available experimental data [21]. The fuel composition and the material set employed to collect the experimental data are the same used in this simulation. Although several limitations affect the accuracy of the degradation expression, due to the small data pool present in the literature, qualitative trends of degradation rate can be represented in order to study the cell behavior during time. Since degradation is represented by a simple algebraic expression, the effect different material sets or fuel compositions could be easily modeled by changing the numerical coefficients of Eq. 10. Future work will focus on the uncertainty related to the experimental data and the fitting method, in order to evaluate the quantitative impact on fuel cell life estimation.

Water-gas shifting reaction, presented in Equation 12, is considered at the equilibrium. The equilibrium constant is presented in Equation 13. Direct internal methane reforming is also taken into account, considering first order reaction kinetics with respect to methane partial pressure. Methane consumption rate is calculated according with Equation 14. However, methane is not present in the fuel considered in this work.

$\mathrm{H}_{2}+\mathrm{CO} \leftrightarrow \mathrm{CO}_{2}+\mathrm{H}_{2} \mathrm{O}$

$K_{p, s h i f t}=\frac{p_{H_{2}} p_{C O_{2}}}{p_{H_{2}} O p_{C O}}=\exp \left(\frac{4276}{T}-3.961\right)$

$r_{s r}=4328.61 \cdot p_{C H_{4}} \exp \left(-\frac{82000}{R_{g} T}\right) \cdot A_{\text {react }}$

Temperature profiles of cathode stream and solid material are solved with an implicit/explicit finite difference method, via a tri-diagonal matrix algorithm. The model accounts for the heat generated by the chemical reactions $q_{g e n}$, the conductive heat transfer in the solid material, and the convective transfer between air flow and solid, as illustrated in Equation 15.

$k A_{\text {channel }} \frac{\partial^{\mathrm{x}} T}{\partial x^{2}}+h A_{\text {gas }}\left(T_{\infty}-T\right)+q_{\text {gen }}=\rho_{s} c_{p} A_{\text {channel }} \frac{\partial T}{\partial t}$ 
More details on the SOFC model and the numerical coefficients employed can be found in a previous publication by Hughes et al. [24].

\section{Test procedure}

The geometry of the cell considered for this test is presented in Table 1. Fuel and air flows are divided into 50 channels each, at the anode and cathode side respectively.

\begin{tabular}{|l|l|}
\hline Number of cells & 2200 \\
\hline Area & $400 \mathrm{~cm}^{2}$ \\
\hline Anode thickness & $0.5 \mathrm{~mm}$ \\
\hline Cathode thickness & $0.05 \mathrm{~mm}$ \\
\hline Electrolyte thickness & $0.008 \mathrm{~mm}$ \\
\hline Cell length & $200 \mathrm{~mm}$ \\
\hline Cell width & $200 \mathrm{~mm}$ \\
\hline Gas channel width & $2 \mathrm{~mm}$ \\
\hline Number of channels & 50 \\
\hline
\end{tabular}

Table 1. Geometry parameters of the cell

Nominal operating conditions are illustrated in Table 2. Target current, airflow and fuel flow were kept constant during the simulation and equal to their nominal value, letting the cell power degrade.

\begin{tabular}{|l|l|}
\hline Cathode air flow & $1.00 \mathrm{~kg} \cdot \mathrm{s}^{-1}$ \\
\hline Cathode inlet temperature & $690^{\circ} \mathrm{C}$ \\
\hline Cathode inlet pressure & $0 \mathrm{kPag}(1 \mathrm{~atm})$ \\
\hline Current & $200 \mathrm{~A}$ \\
\hline Average current density & $0.5 \mathrm{~A} \cdot \mathrm{cm}^{-2}$ \\
\hline Fuel flow & $95 \mathrm{~g} \cdot \mathrm{s}^{-1}$ \\
\hline Fuel utilization & $80 \%$ \\
\hline Average cell temperature & $820^{\circ} \mathrm{C}$ \\
\hline Fuel composition & $29.1 \% \mathrm{H}_{2}, 27.1 \% \mathrm{H}_{2} \mathrm{O}, 28.6 \% \mathrm{CO}$, \\
& $12 \% \mathrm{CO}_{2}, 0.32 \% \mathrm{~N}_{2}$ \\
\hline
\end{tabular}

Table 2. Nominal operating conditions

The results for the equivalent of 12,000 hours, at constant total current, fuel utilization, and airflow, are presented in the following sections. The model was run to reach steady state conditions and then the degradation was applied to the cell. In the following charts, the "time $=0$ " is the moment when the degradation started, i.e. it shows the steady state profiles before the cell starts degrading. The time was chosen to achieve a final voltage of approximately $0.65 \mathrm{~V}$, at 
which the nickel normally starts to re-oxidize, causing a sudden failure of the cell. Results below that voltage were not considered of practical interest. Also, below this voltage the convergence loop in the model shows instabilities and the results loose accuracy. However, the experimental data used to extrapolate the degradation rate expression were collected for less than 3,000 hours of operation. Thus, the following results give a qualitative idea of the trends, but the cell behavior for long operating time is not supported by experimental data.

\section{Results and discussion}

A detailed analysis of key operating parameters behavior during cell degradation is presented in this section. With the chosen $\mathrm{H}_{2}$-rich syngas composition, before the cell starts degrading, current density is higher at the cell inlet and lower at the end. Fuel utilization is higher at the inlet and in the center of the cell, while the solid temperature is lower at the inlet. All these factors contribute to degrade the first part of the cell faster according to the expression in Eq. 10. Resistance increases at the inlet, shifting the current density peak towards the outlet. Temperature decreases at the beginning of the cell where less current is generated and increases at the end. For this reason the degradation rate decreases at the inlet due to the lower current density, but after 2,000 hours the decrement is slow because the temperature is decreasing too. In the last part of the cell the high temperature contributes lowering the global resistance thanks to two factors: lower degradation rate and inverse dependence of ohmic resistance from temperature. Since the resistance is lower, the current density keeps increasing at the end of the cell, incrementing the temperature even more. The inter-dependence between each parameter for each node in the model is summarized in Figure 1.

\subsection{Current density}

The evolution of current density profile during time from the initiation of degradation is shown in Figure 2. With the chosen fuel composition, at the beginning of the cell life the current density is higher between node 2 and node 6. Then it slowly decreases following the hydrogen concentration, presented in Figure 3a, since hydrogen is assumed to be the only species that is directly oxidized in the electrochemical process. During the $12,000 \mathrm{~h}$ of simulation, current density decreases significantly at the inlet, and the peak shifts towards the center first, and then to the end of the cell. The peak in localized current density increases with time. The value at the 
cell outlet increases as well, since the total current is constrained to be constant (hence, the average current density is constant as well).

\section{$\underline{4.2 \text { Composition }}$}

Hydrogen and $\mathrm{CO}$ concentrations are presented in Figures $3 \mathrm{a}$ and $\mathrm{b}$. In the first part of the cell, where less current is generated, $\mathrm{H}_{2}$ mole fraction increases with time. Since hydrogen is a product of the water-gas shift (WGS) reactions, an increment in its concentration, and the consequent reduction in water, shifts the WGS equilibrium toward the reactants side. For this reason $\mathrm{CO}$ mole fraction increases with time in the beginning of the cell.

The reduction in $\mathrm{H}_{2}$ in the end of the cell becomes sharper as time proceeds, and it is related to the peak in local current density. The slope of the concentration curve is higher in the node that corresponds to the current density maximum. From the beginning of life to $12,000 \mathrm{~h}$ of operation, the change in slope happens closer to the cell outlet, consistently with the peak in current density. As $\mathrm{H}_{2}$ is consumed faster, the equilibrium of WGS reaction is shifted toward the products in the last part of the cell. Electrochemical oxidation of $\mathrm{H}_{2}$ is driven by higher temperatures in the last part of the cell, as the peak in current density shows. Even if high temperature contributes to shift the equilibrium of WGS reaction toward the reactant, the high consumption of $\mathrm{H}_{2}$ and consequent formation of water drive the equilibrium to the products side.

Concentration of water and $\mathrm{CO}_{2}$ are shown in Figures $3 \mathrm{c}$ and $\mathrm{d}$. They reflect the trends of $\mathrm{H}_{2}$ and $\mathrm{CO}$ concentration profiles. Water is produced in the electrochemical reactions and is consumed in the WGS reactions, consequently its mole fraction decreases with time in the beginning and in the center of the cell where hydrogen mole fraction increases. The same happens to $\mathrm{CO}_{2}$ mole fraction, as a consequence of $\mathrm{CO}$ utilization along the cell.

\section{$\underline{4.3 \text { Fuel utilization }}$}

Fuel utilization, presented in Figure 4, depends on the consumption of hydrogen and CO. In the beginning of the cell life, fuel utilization increases from node 1 to node 2 because of the increased electrochemical oxidation in the first $10 \%$ of the cell length, as indicated by the initial peak in current density. Then the fuel utilization keeps increasing gradually along the cell until peaking at node 12 or $60 \%$ of the cell length, where it starts decreasing because of the reduced 
current requirements at the end of the cell. Overall, the fuel utilization at the start is quite uniform, not contributing significantly to the initial localized degradation.

As time proceeds, fuel utilization behavior is driven by $\mathrm{H}_{2}$ and $\mathrm{CO}$ mole fraction trends. As previously shown, the consumption of hydrogen and $\mathrm{CO}$ becomes lower in the first part of the cell, lowering the fuel utilization, and higher in the last nodes, where the fuel utilization increases. The maximum fuel utilization is found closer to the cell outlet. This peak, together with the highest current density value, contribute to increase the degradation rate at the end of the cell during time.

\section{$\underline{4.4 \text { Temperatures }}$}

The solid temperature profile, shown in Figure 5a, depends on the heat generated by the electrochemical reactions and the transferred heat to the airflow in each node. Solid temperature increases along the cell with a non-linear trend, because the reactions are taking place, and because the air temperature is increasing as well, as shown in Figure 6, reducing the $\Delta \mathrm{T}$ between solid and air and consequently the heat flux from solid to gas.

As degradation occurs, the decreased current density is followed by a reduction in solid temperature. The variation in average solid temperature is illustrated in Figure 5b. Although the temperature profile along the cell significantly changes during time, the average temperature changes only 5 degrees. The change in solid temperature profile primarily drives the change in heat flux from solid to air. For this reason, gas temperature decreases in the first $70 \%$ and increased in the last $30 \%$ of the cell length.

\section{$\underline{4.5}$ Degradation rate and resistance}

Degradation rate profiles, shown in Figure 7, are a consequence of the behavior of current density, fuel utilization and temperature. Degradation rate shows an initial peak between node 2 and 4, where current density and fuel utilization are high and temperature is lower. At the beginning of the cell life, it is almost zero in the last 4 nodes, thanks to a higher temperature and low current density.

During the first 2,000 h, degradation rate decreases fast in the first nodes, as a consequence of reduced current density and fuel utilization. After 2,000 h it decreases more slowly with time 
because of the reducing temperature, whose effect of increasing the degradation rate contrasts the low current density and fuel utilization impact. In the last half of the cell, the rate increases slightly because of the increment in current density, but the high temperature keeps the degradation rate low. At $12,000 \mathrm{~h}$ the degradation rate is between 0.2 and 0.5 in every point of the cell, showing a fairly uniform distribution.

Total cell resistance is affected by two factors: temperature, which decreases the ohmic resistance of PEN as it increases, and degradation rate, which contributes to increment total resistance as the cell is degrading. The contribution of degradation is cumulative, so the resistance keeps increasing with time even though the degradation rate is reducing. The idea is that once a part of the cell degrades, the resistance increases irreversibly, and at the following sample time the impact of degradation affects the new resistance.

The total resistance is much higher at the inlet where temperature is lower, and it increases significantly with time due to the degradation rate effect and the temperature reduction, as Figure 8 shows. In the last nodes, where the temperature is higher and the degradation rate lower, the resistance is very low. As the degradation rate increases, the resistance shows a slight increment also at the outlet, but it is almost negligible. For this reason, local current density keeps increasing in the second part of the cell.

A summary of the behavior of the main parameters after $12,000 \mathrm{~h}$ is presented in Table 3 .

\begin{tabular}{l|c|c|c|c|c|}
\cline { 2 - 6 } & $\begin{array}{c}\text { Current } \\
\text { density }\end{array}$ & $\begin{array}{c}\text { Fuel } \\
\text { utilization }\end{array}$ & Temperature & $\begin{array}{c}\text { Degradation } \\
\text { rate }\end{array}$ & Resistance \\
\hline Cell inlet & $\downarrow$ & $\downarrow$ & $\downarrow$ & $\downarrow$ & $\uparrow$ \\
\hline Cell outlet & $\uparrow$ & $\uparrow$ & $\uparrow$ & - & - \\
\cline { 2 - 6 }
\end{tabular}

Table 3. Summary of key parameters behavior after $12,000 \mathrm{~h}$ of operation

\section{Conclusion}

The analysis of the key fuel cell parameters during cell degradation was carried out with a distributed model. Degradation was taken into account as an increment in ohmic resistance, as a function of the following operating parameters: current density, fuel utilization, and temperature. These parameters were chosen because they are proved to impact cell degradation, and because they can be measured and controlled during the operations in order to mitigate degradation 
effects. The use of a simple algebraic expression allows to maintain real-time performance of the model.

Fed with syngas, the cell degrades immediately at the inlet, where current density and fuel utilization are higher, and temperature is lower. This increases the resistance at the inlet, shifting the current density peak toward the end of the cell. After 500 hours at constant total current, fuel flow and airflow, current density and fuel utilization are higher in the center of the cell, which start degrading as well. After 1,000 h temperature decreases at the inlet, which has a negative impact on local degradation rate, and increases at the outlet, keeping the resistance and the degradation rate low. After 2,000 h the current density peak is shifted to the cell outlet where the resistance is lower, and it increases significantly with time. After around 12,000 $\mathrm{h}$, the degradation rate is fairly uniform along the cell.

An analysis of more fuel cell parameters and potential issues during cell degradation is the object of the Part II of this paper.

\section{Acknowledgment}

This work was funded by the U.S. Department of Energy (DOE) Crosscutting Research Program of the National Energy Technology Laboratory (NETL). The authors would like to thank Dr. Paolo Pezzini from Ames Laboratory (IA), Nor Farida Harun from MacMaster University (Canada) and Dr. Kirk Gerdes from NETL.

\section{References}

[1] K. Haga, S. Adachi, Y. Shiratori, K. Itoh, K. Sasaki, Poisoning of SOFC Anodes by Various Fuel Impurities, Solid State Ionics 179 (2008) 1427- 1431.

[2] K. Park, S. Yu, J. Bae, H. Kim, Y. Ko, Fast Performance Degradation of SOFC Caused by Cathode Delamination in Long-term Testing, International Journal of Hydrogen Energy 35 (2010) 8670-8677.

[3] D.E. Vladikova, Z.B. Stoynov, A. Barbucci, M. Viviani, Impedance Studies of Cathode/Electrolyte Behavior in SOFC, Electrochimica Acta 53 (2008) 7491-7499.

[4] G.J. Offer, N.P. Brandon, The Effect of Current Density and Temperature on the Degradation of Nickel Cermet Electrodes by Carbon Monoxide in Solid Oxide Fuel Cells, Chemical Engineering Science 64 (2009) 2291-2300. 
[5] V. Verda, M.R. von Spakovsky, Development of a Detailed Planar Solid Oxide Fuel Cell Computational Fluid Dynamics Model for Analyzing Cell Performance Degradation, Journal of Fuel Cell Science and Technology 6 (2009) DOI: 10.1115/1.2971046.

[6] A.V. Virkar, A model for solid oxide fuel cell (SOFC) stack degradation, Journal of Power Sources 172 (2007) 713-724, DOI: 10.1016/j.jpowsour.2007.05.076.

[7] E.M. Ryan, W. Xu, X. Sun, M.A. Khaleel, A damage model for degradation in the electrodes of solid oxide fuel cells: Modeling the effects of sulfur and antimony in the anode, Journal of Power Sources 210 (2012) 233-242.

[8] J.I. Gazzarri, O. Kesler, Electrochemical AC impedance model of a solid oxide fuel cell and its application to diagnosis of multiple degradation modes, Journal of Power Sources 167 (2007) 100-110.

[9] F.P. Nagel, T.J. Schildhauer, J. Sfeir, A. Schulerb, S.M.A. Biollaz, The impact of sulfur on the performance of a solid oxide fuel cell (SOFC) system operated with hydrocarboneous fuel gas, Journal of Power Sources 189 (2009) 1127-1131, DOI: 10.1016/j.jpowsour.2008.12.092.

[10] A. Nakajo, F. Mueller, J. Brouwer, J. van Herle, D. Favrat, Progressive activation of degradation processes in solid oxide fuel cells stacks: Part I: Lifetime extension by optimisation of the operating conditions, Journal of Power Sources 216 (2012) 449-463, DOI:10.1016/j.jpowsour.2012.05.078.

[11] J.P. Trembly, A.I. Marquez, T.R. Ohrn, D.J. Bayless, Effects of coal syngas and H2S on the performance of solid oxide fuel cells: Single-cell tests, Journal of Power Sources 158 (2006) 263-273.

[12] H. Tu, U. Stimming, Advances, Aging Mechanisms and Lifetime in Solid Oxide Fuel Cells, Journal of Power Sources, 127 (2004) 284-293, DOI:

10.1016/j.jpowsour.2003.09.025.

[13] R.R. Liu, S.H. Kim, S. Taniguchi, T. Oshima, Y. Shiratori, K. Ito, K. Sasaki, Influence of water vapor on long-term performance and accelerated degradation of solid oxide fuel cell cathodes, Journal of Power Sources 196 (2011) 7090-7096.

[14] A. Hagen, R. Barfod, P.V. Hendriksen, Degradation of Anode Supported SOFCs as a Function of Temperature and Current Load, J. of Electrochem. Soc., 153 (2006) A1165A1171.

[15] L. de Haart, J. Mougin, O. Posdziech, J. Kiviaho, N. Menzler, Stack Degradation in Dependence of Operation Parameters; the Real-SOFC Sensitivity Analysis, Fuel Cell 9 (6) (2009) 794-804, DOI: 10.1002/fuce.200800146. 
[16] H. Yokokawa, H. Tu, B. Iwanschitz, A. Maic, Fundamental mechanisms limiting solid oxide fuel cell durability, Journal of Power Sources, 182 (2008) 400-412, DOI:10.1016/j.jpowsour.2008.02.016.

[17] M. Linder, T. Hocker, C. Meier, L. Holzer, K.A. Friedrich, B. Iwanschitz, A. Mai, J.A. Schuler, A model-based approach for current voltage analyses to quantify degradation and fuel distribution in solid oxide fuel cell stacks, Journal of Power Sources 288 (2015) 409-418, DOI: 10.1016/j.jpowsour.2015.04.136.

[18] R.S. Gemmen, M.C. Williams, K. Gerdes, Degradation measurement and analysis for cells and stacks, Journal of Power Sources 184 (2008) 251-259, DOI:

10.1016/j.jpowsour.2008.06.047.

[19] M. Abreu-Sepulveda, N.F. Harun, G. Hackett, A. Hagen, D. Tucker, Accelerated Degradation for Hardware in the Loop Simulation of Fuel Cell Gas Turbine Hybrids, Journal of Fuel Cell Science and Technology, 12 (2015), DOI: 10.1115/1.4028953.

[20] D. Tucker, M. Abreu-Sepulveda, N.F. Harun, SOFC lifetime assessment in gas turbine hybrid power systems, Journal of Fuel Cell Science and Technology, 11 (2014), DOI: $10.1115 / 1.4028158$.

[21] V. Zaccaria, D. Tucker, A. Traverso, A Real-time Degradation Model for Hardware in the Loop Simulation of Fuel Cell Gas Turbine Hybrid Systems, Proceedings of ASME Turbo Expo 2015, Montreal, Canada, Paper number GT2015-43604.

[22] C. Comminges, Q.X. Fu, M. Zahid, N.Y. Steiner, O. Bucheli, Monitoring the degradation of a solid oxide fuel cell stack during $10,000 \mathrm{~h}$ via electrochemical impedance spectroscopy, Electrochimica Acta, 59 (2012) 367-375.

[23] V. Zaccaria, D. Tucker, A. Traverso, A distributed real-time model of degradation in a solid oxide fuel cell, Part II: Analysis of fuel cell performance and potential failures, Journal of Power Sources.

[24] D. Hughes, W.J. Wepfer, K. Davies, J.C. Ford, C. Haynes, D. Tucker, A Real-time Spatial SOFC Model for Hardware-Based Simulation of Hybrid Systems, International ASME Conference on Fuel Cell Science, Engineering and Technology 2011.

[25] D. Tucker, M. Shelton, A. Manivannan, The Role of Solid Oxide Fuel Cells in Advanced Hybrid Power Systems of the Future, Interface (2009) 25-28.

[26] D.A. Noren, M.A. Hoffman, Clarifying the Butler-Volmer Equation and Related Approximations for Calculating Activation Losses in Solid Oxide Fuel Cell Models, Journal of Power Sources, 152 (2005) 175-181. 


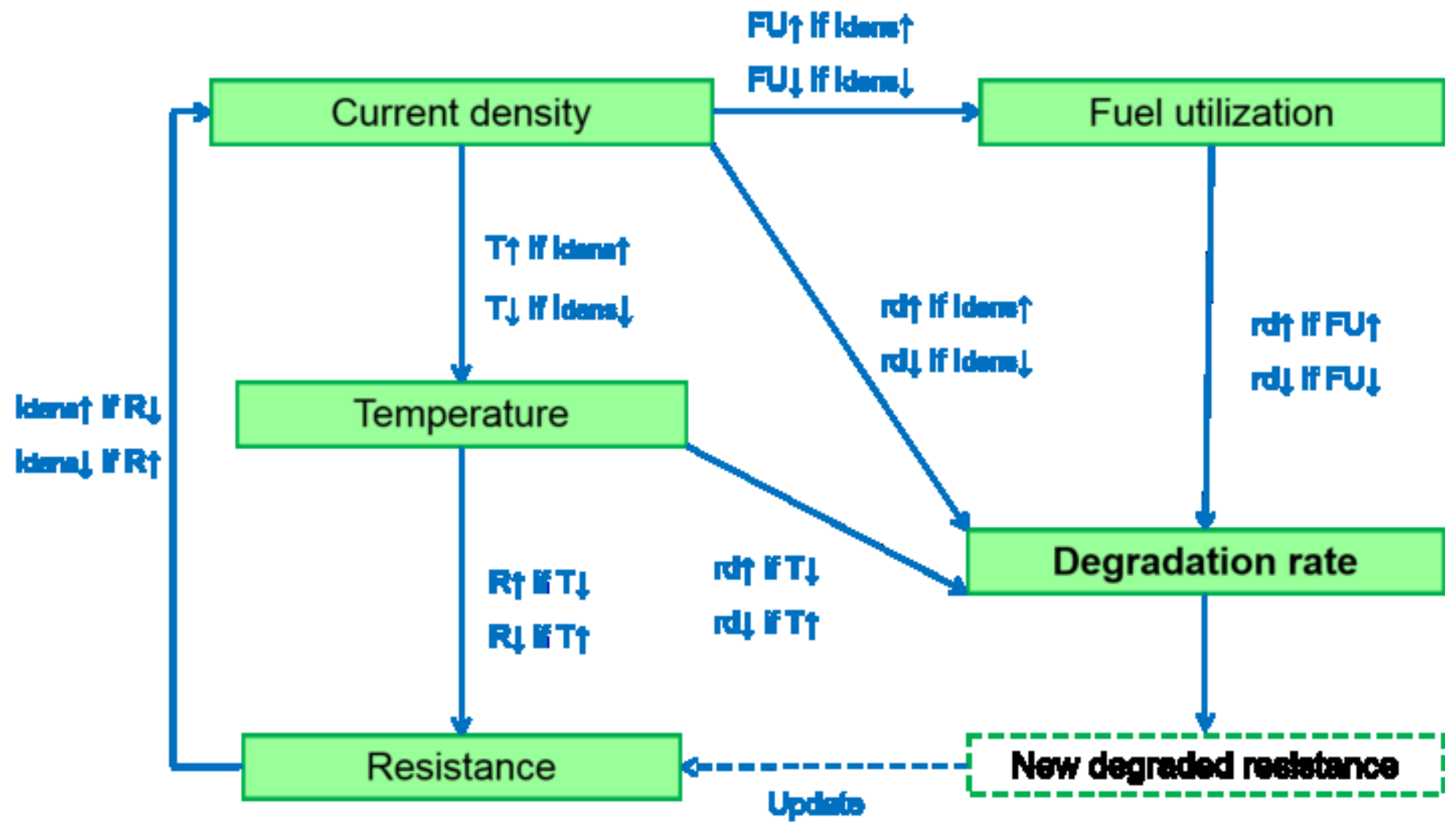




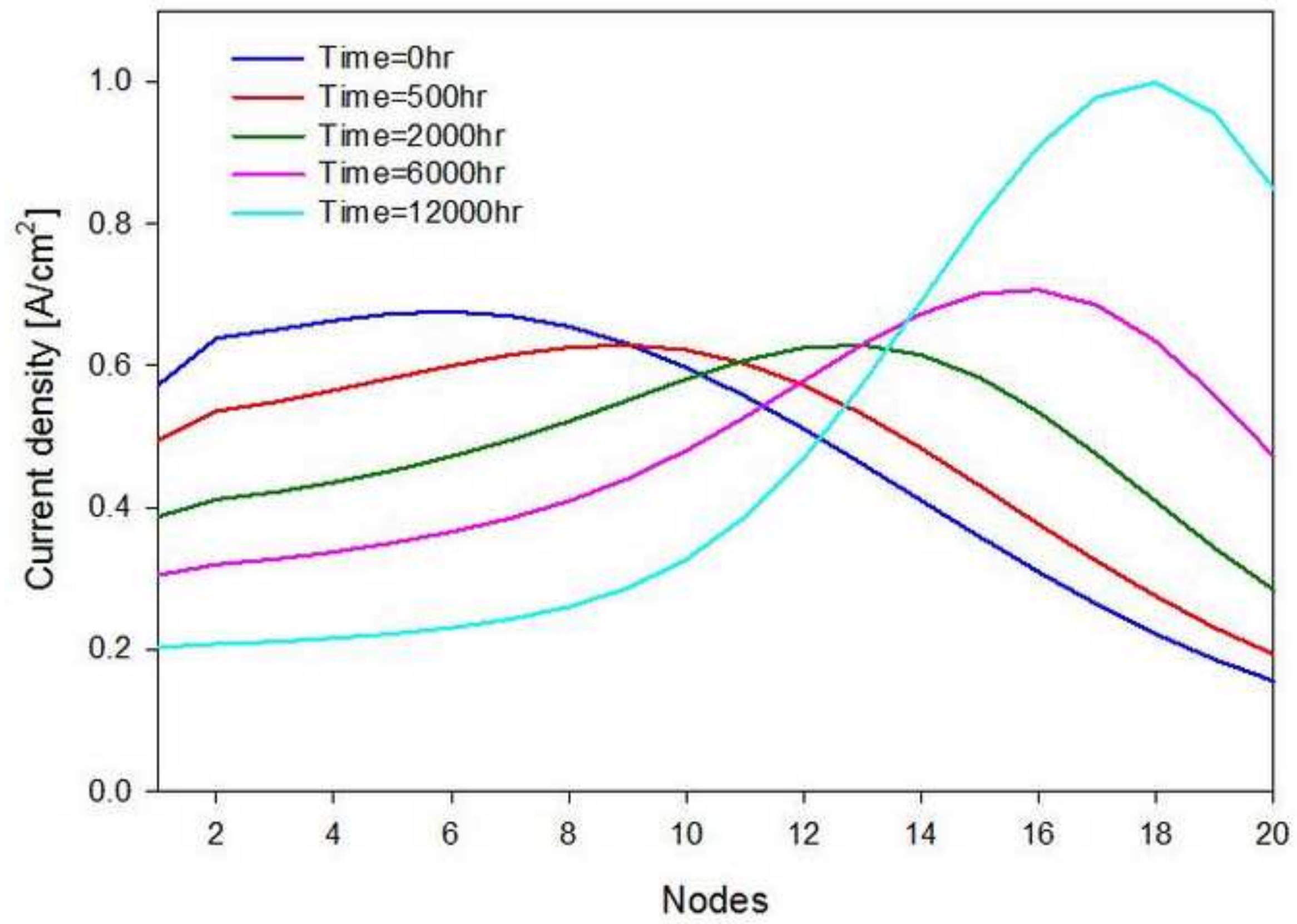




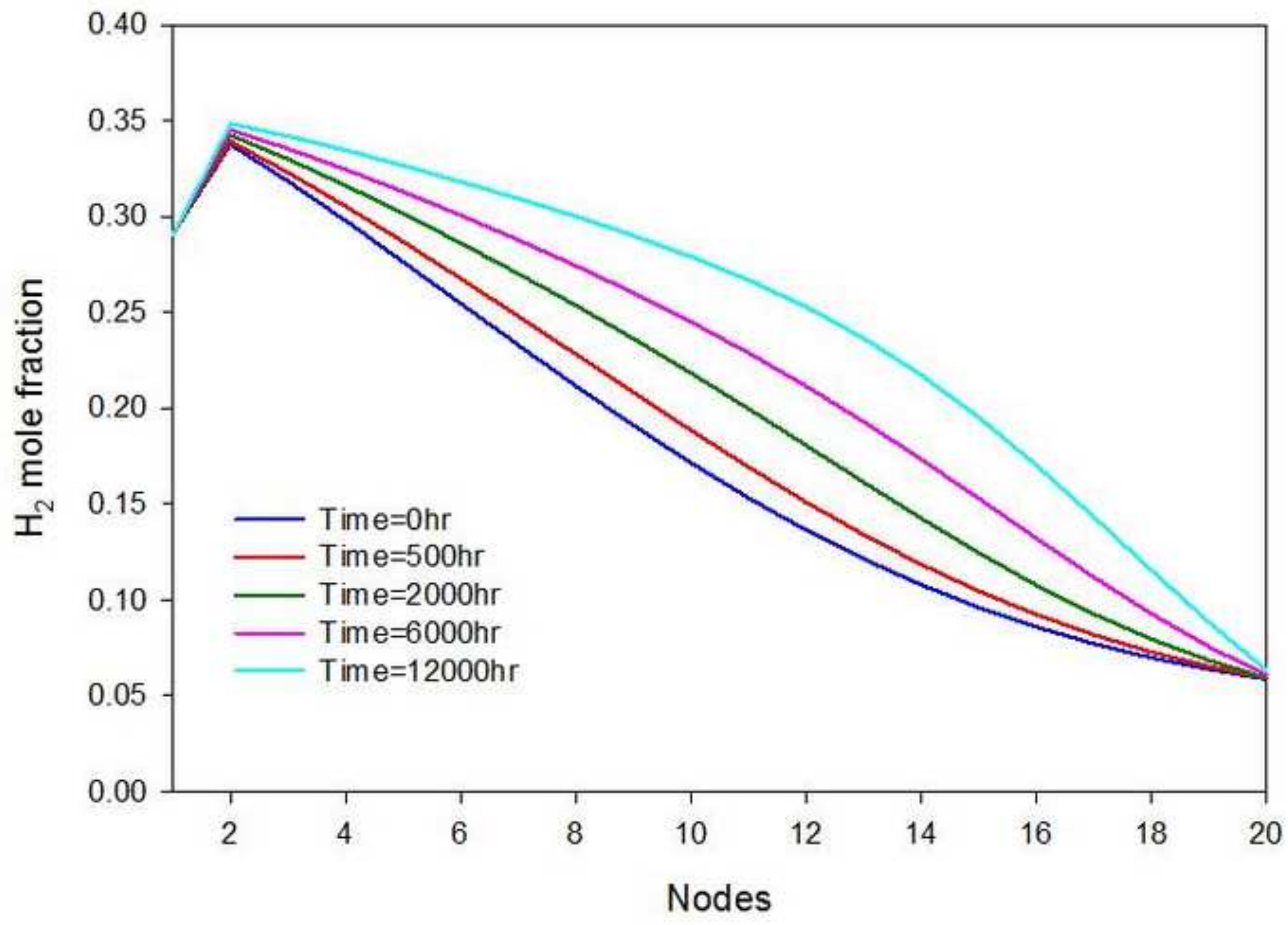




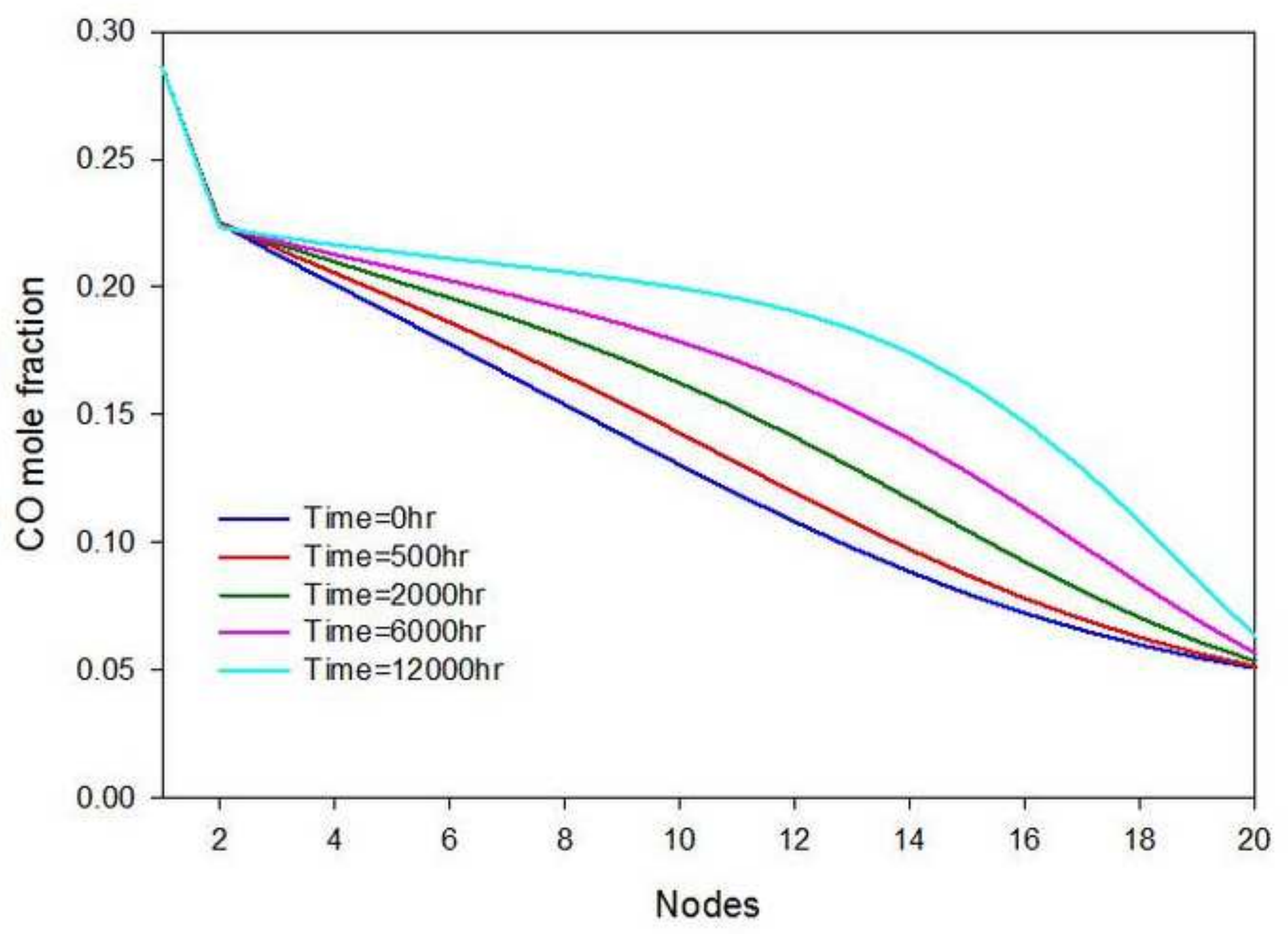

Figure $3 b$ 


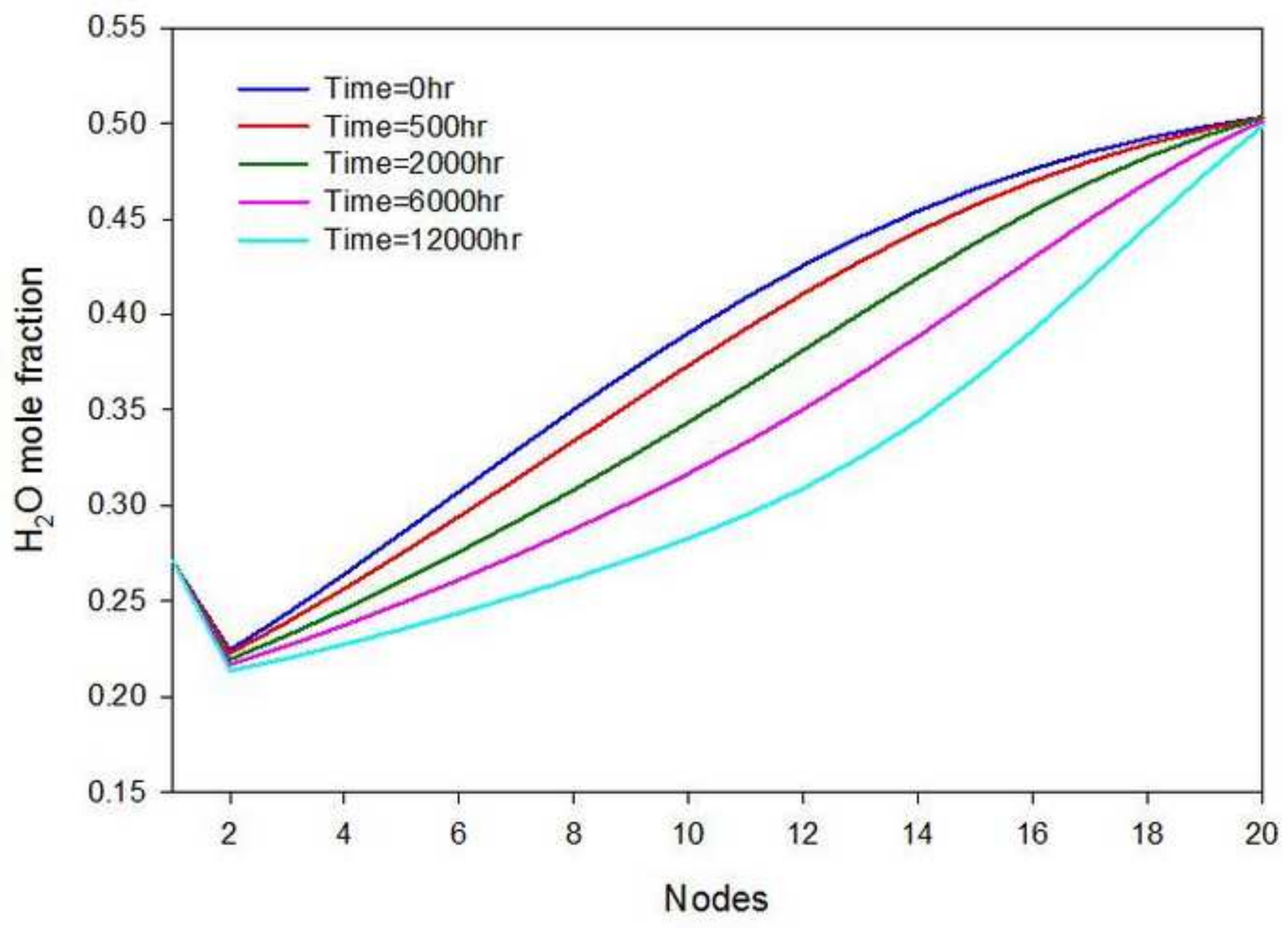




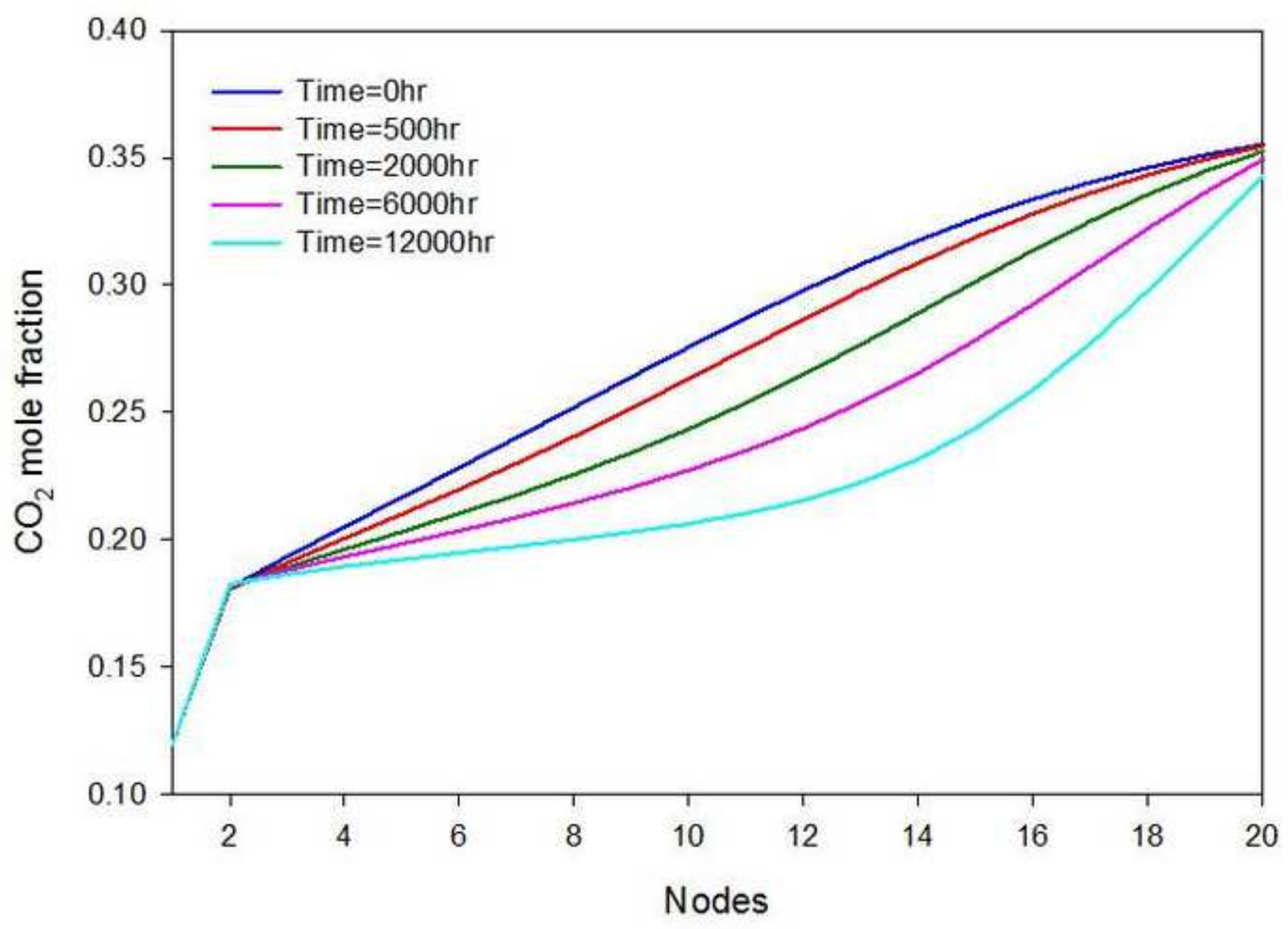




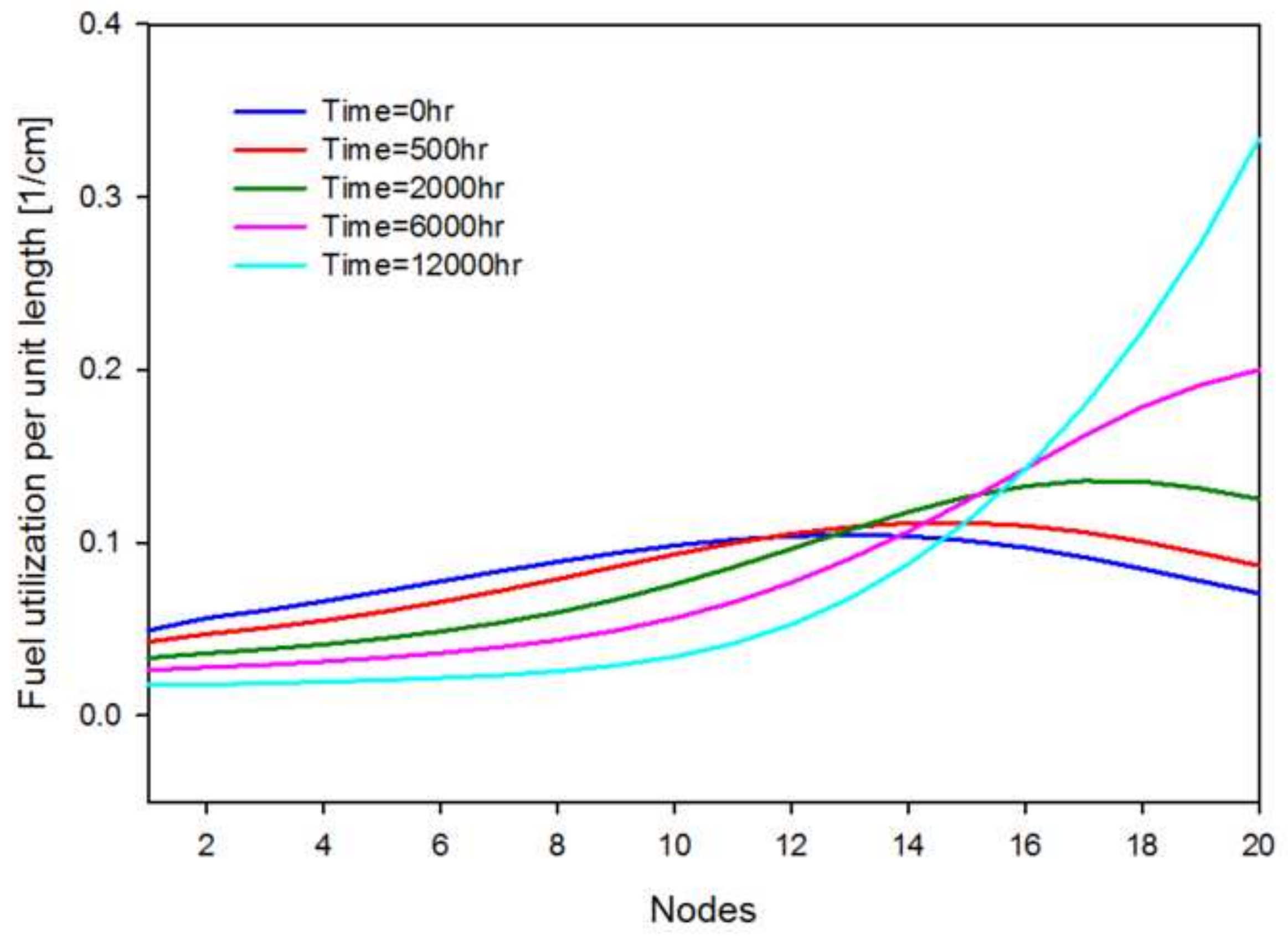




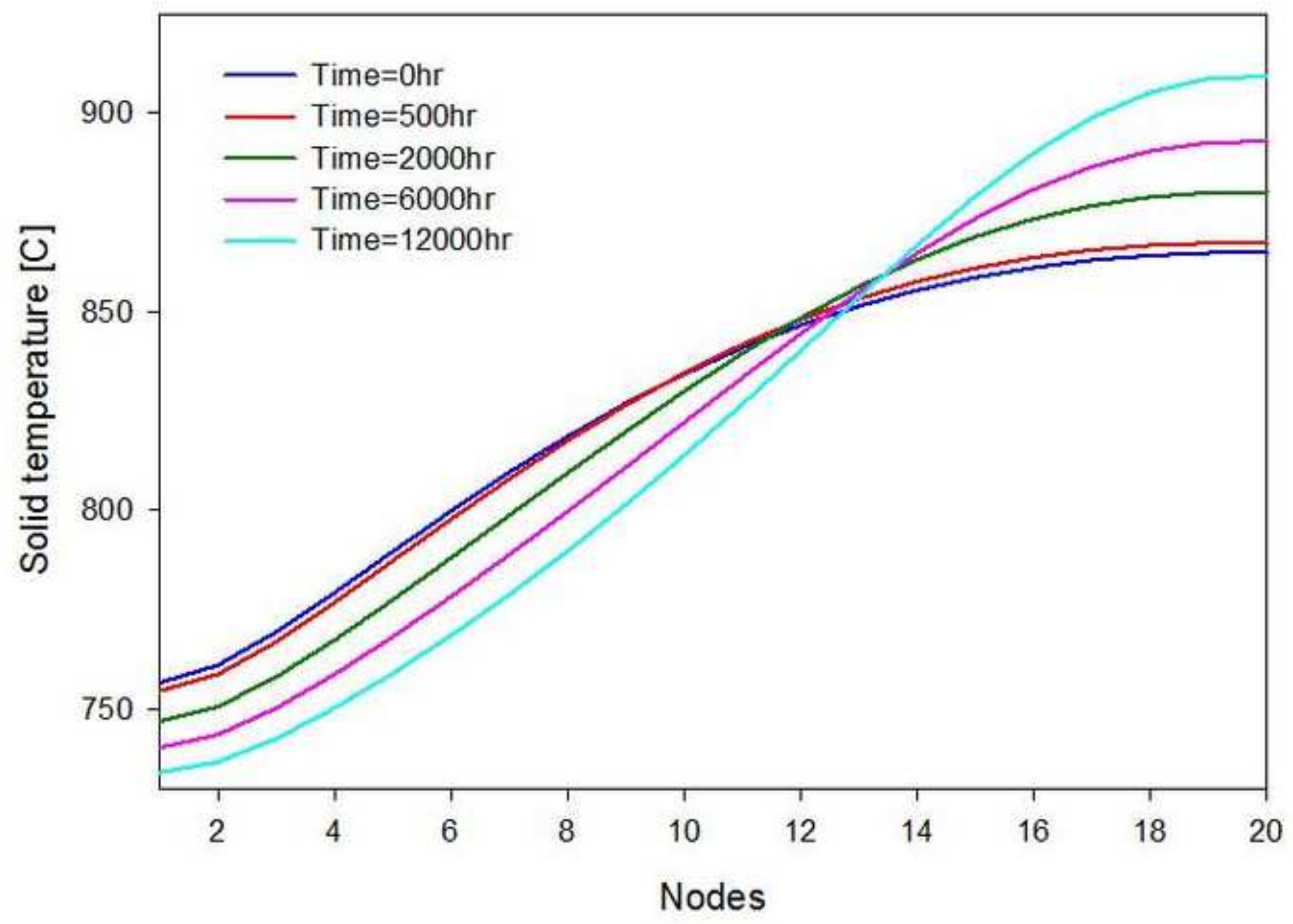




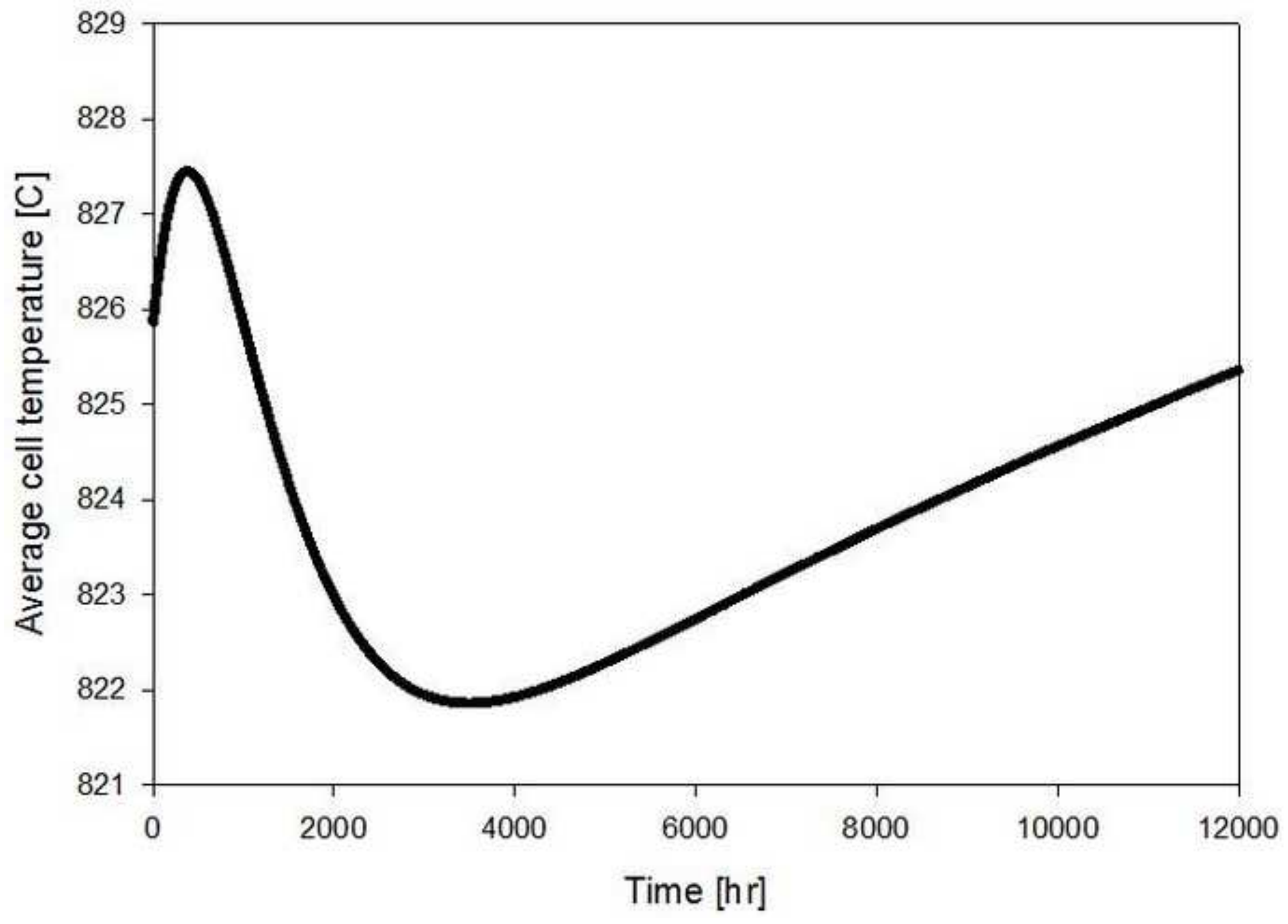




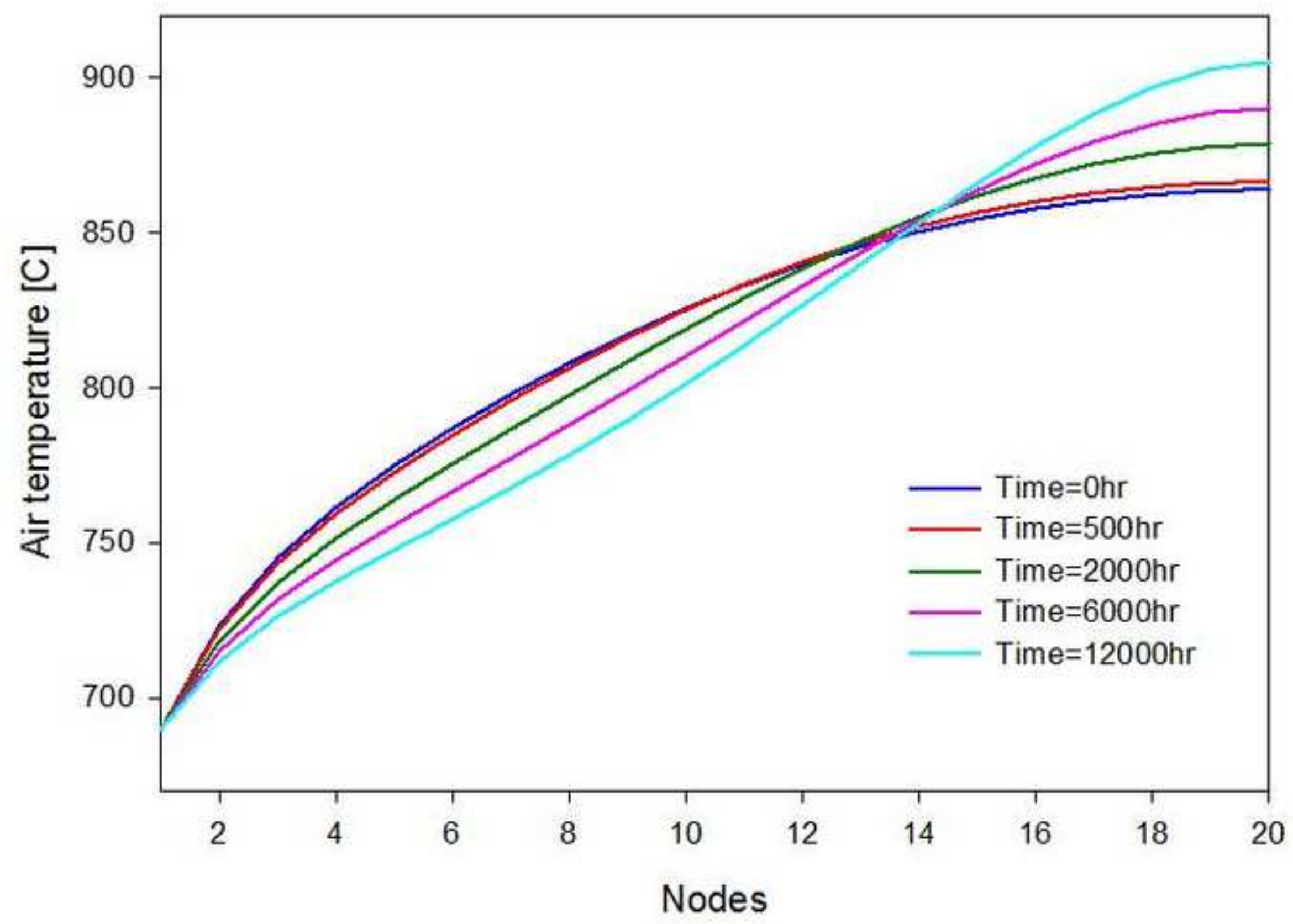




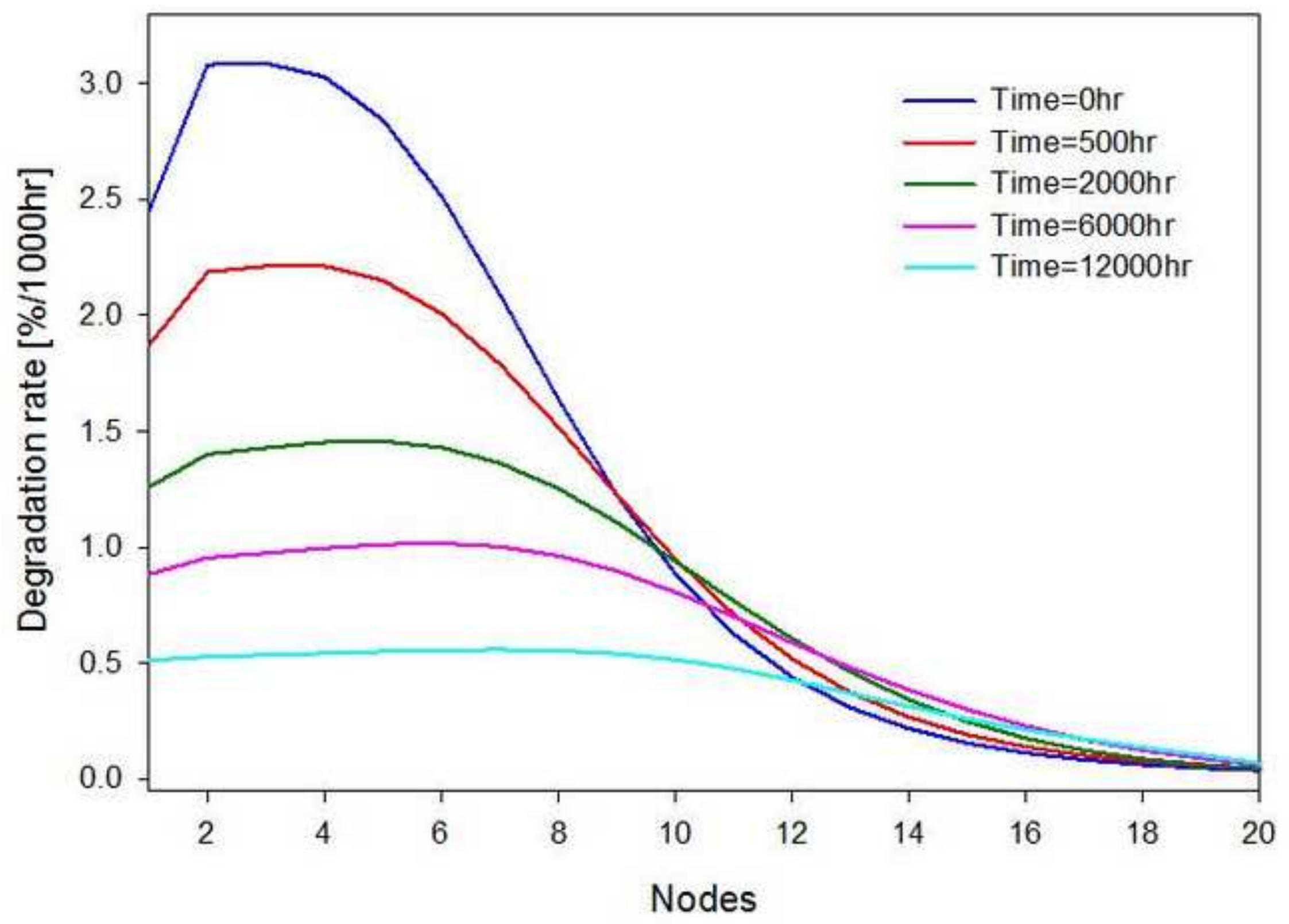




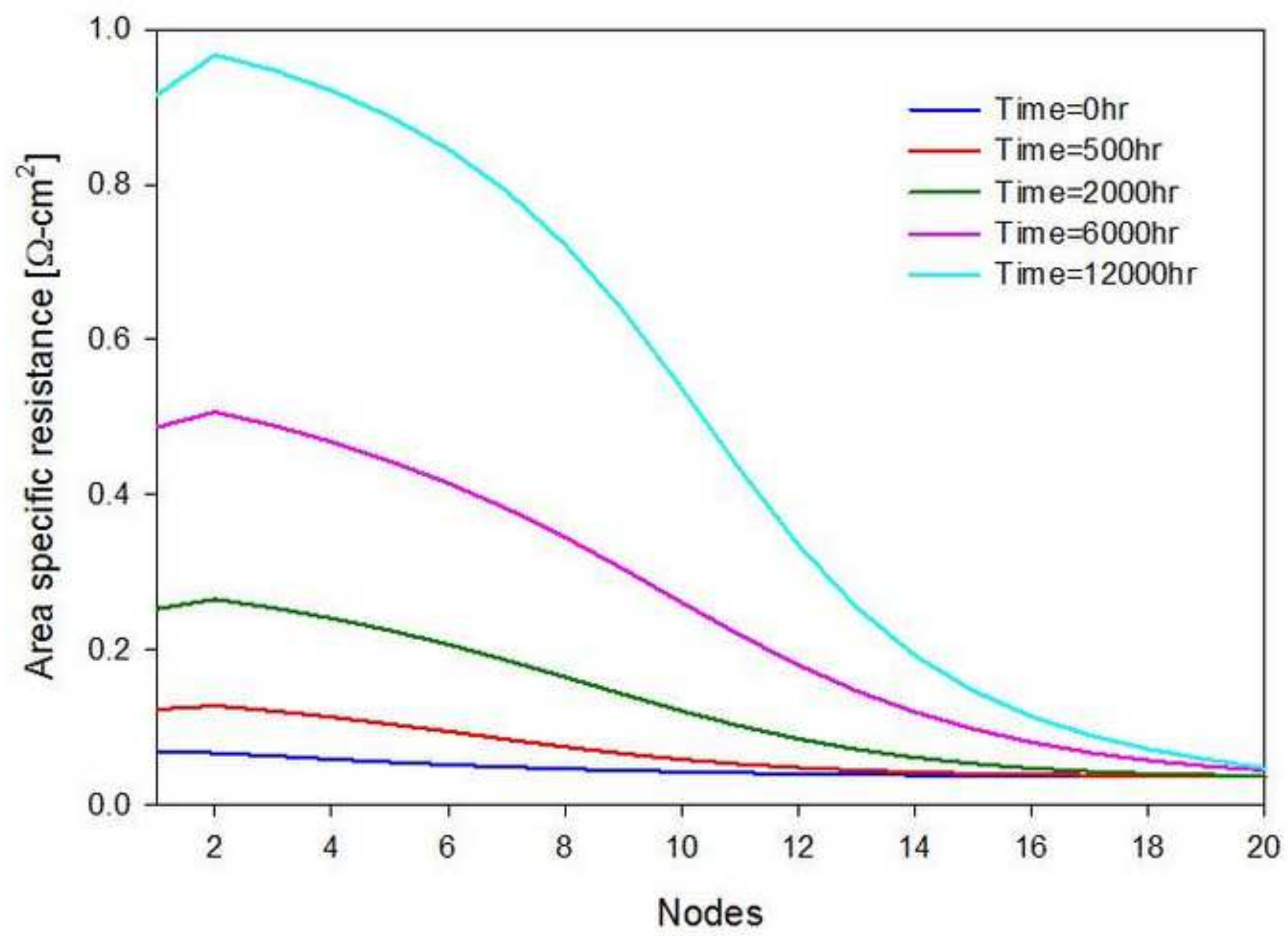




\section{Figures caption}

Fig. 1 Degradation loop

Fig. 2 Current density profiles along the cell at different time

Fig. 3a $\mathrm{H}_{2}$ concentration profiles along the cell at different time

Fig. 3b CO concentration profiles along the cell at different time

Fig. 3c $\mathrm{H}_{2} \mathrm{O}$ concentration profiles along the cell at different time

Fig. 3d $\mathrm{CO}_{2}$ concentration profiles along the cell at different time

Fig. 4 Fuel utilization profile along the cell at different time

Fig. 5a Solid temperature profiles along the cell at different time

Fig. 5b Average cell temperature trend

Fig. 6 Air temperature profiles along the cell at different time

Fig. 7 Degradation rate profiles along the cell at different time

Fig. 8 Resistance profiles along the cell at different time 